\title{
Effect of Foliar Application of Vegetable Special on Growth and Yield of Potato
}

\author{
S. Channakeshava*, T.S. Manjunathaswamy, H.K. Pankaja and G.S. Krishna Reddy \\ Krishi Vigyan Kendra, University of Agricultural Sciences, Kandali, Hassan-573217, \\ Bengaluru, Karnataka, India \\ *Corresponding author
}

\section{A B S T R A C T}

An on farm testing on effect of foliar application of vegetable special on growth and yield of potato was conducted in farmers' field of Hassan district in five locations during 2015 and 2016 through Krishi Vigyan Kendra, Kandali, Hassan, University of Agricultural Sciences, Bengaluru. The results of the two years pooled data (2015 and 2016) revealed that foliar applications of vegetable special @ 5g/lit recorded significantly higher yield $(103.95 \mathrm{q} / \mathrm{ha})$ and the lowest yield was recorded in farmers practice $(91.3 \mathrm{q} / \mathrm{ha})$. However foliar application of vegetable special @ 3g/lit (98.1q/ha) was on par with recommended

Keywords

Tuberization, Tuber size, Foliar application.

Article Info

Accepted: 19 July 2017 Available Online: 10 September 2017 practice $(95.1 \mathrm{q} / \mathrm{ha})$. The increase in yield was 13.85 percent with foliar application of vegetable special @ 5g/lit along with recommended dosage of fertilizer compared to farmers practice. Recommended practice and alternate practice-1 recorded 5.96 percent and 9.07 percent increase in yield compared to farmers practice. The similar trend was observed with respect to yield parameters of potato. However, significantly higher number of tubers and tuber weight was recorded with RDF+ foliar spray of vegetable special @ $5 \mathrm{~g} / \mathrm{lit}(9.7$ and $1.46 \mathrm{~kg})$ compared to farmers practice $(4.5$ and $0.62 \mathrm{~kg})$. Lowest number of tubers per plant and tuber weight was recorded in farmers' practice (4.5 and 0.62). However similar number of tubers and tuber weight was recorded with recommended practice $(5.6$ and $0.81 \mathrm{~kg}$ and alternate practice-2 $(7.7$ and $1.18 \mathrm{~kg})$. The maximum total number of tubers were recorded in alternate practice-2 (107.35) followed by alternate practice-1 (102.0). However, number of tubers per square meter was on par with farmers' practice (90.67) and recommended practice (97.9). As regard to micronutrient content in tubers higher concentration of $\mathrm{Zn}, \mathrm{Cu}, \mathrm{Mn}, \mathrm{Fe}, \mathrm{B}$ and $\mathrm{Mo}$ were recorded in the treatment where foliar application of vegetable special @ 5g/lit along with RDF (22.2, 8.3, 21.5, 25.0 and 16.6) than recommended practice and farmers practice. With respect of economics of crop the higher B: C ratio was recorded with Alternate practice-2 + RDF $(1: 2.44)$ followed by alternate practice-1 (2.30) and recommended practice (2.26). The lowest B: C ratio was recorded in Farmers practice (2.23).

\section{Introduction}

Potato (Solanum tuberosum) is one of the main tubers and nutritious crops, which also is very important due to nutritive value and economical. Potato is a very popular vegetable grown all over the world and is an important food crop grown in more than 150 countries in the world. Potato popularly known as 'The king of vegetables' has emerged as fourth most important food crops in India after rice, wheat and maize. Indian 
agricultural production heavily depends on fertilizer application which results in greater rate of nutrient collapse and soil health problems. Regular depletion of nutrient resources from soils has led to emergence of several nutrient deficiencies. Most of the Indian soils are widely deficient in micronutrients especially $\mathrm{Zn}, \mathrm{Mn}, \mathrm{B}$ and $\mathrm{Fe}$. In most of the productive bowls of the world the yield levels of different crops are showing declining trends in spite of addition of sufficient quantity of fertilizers carrying macro and micronutrients. The efficiency of applied inorganic micronutrients is rather low due to their fixation in the soil.

It is noticed that high yielding crop varieties are mining our soils of all the nutrients especially the micronutrients because their addition as fertilizer element is negligible. Iron and manganese are involved in metabolic processes and these are considered activators of important enzymes (Mengal and Kirkby, 1987). Iron is also a structural component of haemoglobin and cytochrome (Tisdale et al., 1985). Potato has been categorized as less sensitive to Fe deficiency (Rashid and Din. 1992), while moderately sensitive to $\mathrm{Mn}$ toxicity (Lucas and Knezek, 1972). One of the most important issues about increase of crop yield and improving the quality of agricultural products is balanced plant nutrition. Foliar application of nutrients has become an efficient way to increase yield and quality of crops (Romemheld and El-Fouly, 1999). It is evident from the researcher that the yield levels of potato declining mainly due to deficiency of micronutrient in soil and plant.

\section{Materials and Methods}

An on farm testing on effect of foliar application of vegetable special on growth and yield of potato was conducted in farmers field of Hassan district through Krishi Vigyan Kendra, Kandali Hassan, University of Agricultural Sciences, Bengaluru during kharif season of 2015 and 2016. The experiment was laid out in randomised block design (RBD) with 4 treatments replicated 5 times (at 5 locations). The soils of experimental sites were sandy clay loam in texture and the initial physic-chemical properties of experimental sites were analysed using standard procedures (Jackson, 1973) (Table 1). The treatments were imposed in farmers' field in five locations as per the treatment details given below.

T1: Farmers practice (100:90:26 NPK kg/ha)

T2: Recommended Practice (75:75:100 NPK $\mathrm{kg} / \mathrm{ha}$ )

T3: RDF+ Foliar spray of Vegetable special @ 3g/lit

T4: RDF+ Foliar spray of Vegetable special @ $5 \mathrm{~g} / \mathrm{lit}$

\section{Composition of vegetable special}

The vegetable special contains 3.0 percent zinc, 0.5 percent boron, 1.0 percent Manganese, 2.0 percent iron and 0.1percent copper

The crop with variety Kufri Jyothi was sown in plots with row to row distance of $60 \mathrm{~cm}$ and plant to plant distance of $20 \mathrm{~cm}$. The growth parameters were recorded at 60 DAS and 90DAS and yield parameters recorded at harvest. The data were analysed statistically by following standard procedures.

\section{Results and Discussion}

\section{Growth parameters}

Results of pooled data of 2015 and 2016 revealed that at 60 DAS the growth parameters like plant height and number of branches were increased significantly due to foliar spray of vegetable special @ 5g/lit 
along with RDF (36.05 $\mathrm{cm}$ and 4.65) over farmers practice $(39.25 \mathrm{~cm}$ and 3.10$)$. Foliar application of vegetable special @ 3g/lit (37.6 $\mathrm{cm}$ and 4.25) and recommended practice (40.3 cm and 3.25$)$ recorded similar results and were on par with each other. The similar trend was followed at 90 DAS with respect to plant height and number branches during both the years and in pooled data. The increase in growth parameters like plant height and number of branches in alternate practice was due to influence of foliar application of micronutrient which enhanced growth and development of crop. These results are in agreement with findings of Mohamadi (2000) (Table 2).

\section{Yield and yield parameters}

The yield and yield parameters differed significantly due to foliar application of vegetable special over other treatments. Results of the pooled data revealed that significantly higher number of tubers per plant and tuber weight per plant was recorded due to foliar application of vegetable special @ 5g/lit along with $\operatorname{RDF}(9.7$ and $1.46 \mathrm{~kg}$ ) over farmers practice (4.5 and 0.62) and recommended practice (5.6 and 0.81). However, recommended practice and alternate practice-1(7.7 and $1.18 \mathrm{~kg})$ were on par with each other with respect to number of tubers per plant and tuber weight per plant. Several researches indicated a positive influence of micronutrient ( $\mathrm{Zn}, \mathrm{Mn}$ ) application in increase of yield and quantitative parameters of crops (Mosavi et al., 2007) on potato, (Paygozar et al., 2009) on pearl millet As regard to tuber yield per hectare, significantly higher tuber yield of potato per hectare was recorded in alternate practice-2 (103.95q/ha) over other treatments.

Significantly lowest tuber yield was recorded in the farmers practice $(91.3 \mathrm{q} / \mathrm{ha})$ than other treatments. Similar yield levels recorded in recommended practice $(95.3 \mathrm{q} / \mathrm{ha})$ and alternate practice $-1(98.1 \mathrm{q} / \mathrm{ha})$ and were on par with each other. The increase in yield was 13.85 percent in alternate practice over farmers. However percent increase in yield was decreased by 9.07 and 5.96 percent when compared to recommended practice and alternate practice, respectively. Increase in tuber yield per hectare was due to quick compensation of micronutrient through foliar application has satisfied plant demand for micronutrient which helped in better tuberization in turn increased tuber yield. Similar results were also recorded by Horvat et al., (2014) and Mehulparmar (2016) (Table $3)$.

Table.1 Initial physico-chemical properties of experimental site

\begin{tabular}{|c|c|c|c|}
\hline S. No. & Parameters & Value & References \\
\hline 1 & $\mathrm{pH}$ & 6.8 & \multirow[t]{7}{*}{ M.L. Jackson(1965) } \\
\hline 2 & $\mathrm{EC}(\mathrm{ds} / \mathrm{m})$ & 0.23 & \\
\hline 3 & Organic Carbon $(\%)$ & 0.58 & \\
\hline 4 & Available Nitrogen(kg/ha) & 312.5 & \\
\hline 5 & Available Phosphorus (kg/ha) & 65.5 & \\
\hline \multirow[t]{2}{*}{6} & Available Potassium (kg/ha) & 178.6 & \\
\hline & Micronutrient status (DTPA Extractable) in ppm & & \\
\hline 7 & Zinc & 0.65 & \multirow[t]{6}{*}{ CA Black (1973) } \\
\hline 8 & Copper & 0.45 & \\
\hline 9 & Manganese & 0.29 & \\
\hline 10 & Iron & 4.58 & \\
\hline 11 & Boron & 0.22 & \\
\hline 12 & Molybdenum & 0.10 & \\
\hline
\end{tabular}

(Mean of five farmers in the same location.) 
Table.2 Effect of foliar application of vegetable special on growth parameters of potato (Solanum tuberosa)

\begin{tabular}{|c|c|c|c|c|c|c|c|c|c|c|c|c|c|}
\hline \multirow[t]{3}{*}{ S. No. } & \multirow[t]{3}{*}{ Treatments } & \multicolumn{6}{|c|}{ Plant height (cm) } & \multicolumn{6}{|c|}{ Number of branches /plant } \\
\hline & & \multicolumn{3}{|c|}{60 DAS } & \multicolumn{3}{|c|}{90 DAS } & \multicolumn{2}{|c|}{60 DAS } & & \multicolumn{3}{|c|}{90 DAS } \\
\hline & & 2015 & 2016 & Pooled & 2015 & 2016 & Pooled & 2015 & 2016 & Pooled & 2015 & 2016 & Pooled \\
\hline 1 & $\begin{array}{l}\text { Farmers } \\
\text { practice(100:90:26 } \\
\text { kg/ha NPK) }\end{array}$ & 38.5 & 40.0 & 39.25 & 55.6 & 52.5 & 54.05 & 3.0 & 3.2 & 3.10 & 3.4 & 3.8 & 3.6 \\
\hline 2 & $\begin{array}{l}\text { Recommended practice } \\
\text { (75:75:100 NPK kg/ha) }\end{array}$ & 39.6 & 41.0 & 40.3 & 62.5 & 63.4 & 62.95 & 3.5 & 3.0 & 3.25 & 4.5 & 5.2 & 4.8 \\
\hline 3 & $\begin{array}{l}\text { Alternate Practice -1 } \\
\text { RDF+ Foliar spray of } \\
\text { vegetable special @ } \\
3 \mathrm{~g} / \text { lit }\end{array}$ & 38.5 & 36.7 & 37.6 & 63.0 & 62.5 & 62.75 & 4.0 & 4.5 & 4.25 & 4.8 & 5.5 & 5.1 \\
\hline 4 & $\begin{array}{l}\text { Alternate Practice -1 } \\
\text { RDF+ Foliar spray of } \\
\text { vegetable special @ } \\
5 \mathrm{~g} / \text { lit }\end{array}$ & 36.6 & 35.5 & 36.05 & 62.8 & 63.4 & 63.10 & 4.5 & 4.8 & 4.65 & 5.8 & 6.2 & 6.0 \\
\hline & CD (at 5\%) & 0.42 & 0.45 & 0.39 & 0.33 & 0.54 & 0.43 & 0.39 & 0.51 & 0.45 & 0.60 & 0.62 & 0.61 \\
\hline
\end{tabular}

Table.3 Effect of foliar application of vegetable special on yield parameters of potato

\begin{tabular}{|l|l|l|l|l|l|l|l|l|l|l|}
\hline \multirow{2}{*}{$\begin{array}{l}\text { S. } \\
\text { No. }\end{array}$} & Treatments & \multicolumn{2}{l|}{ Number of Tubers/plant } & \multicolumn{2}{l|}{ Tuber weight /plant (kg) } & \multicolumn{2}{l}{ Tuber yield(q/ha) } \\
yield
\end{tabular}


Table.4 Effect of foliar application of vegetable special on micronutrient content in potato tubers

\begin{tabular}{|c|c|c|c|c|c|c|c|c|c|c|c|c|c|c|c|c|}
\hline \multirow[t]{3}{*}{ S. No. } & \multirow[t]{3}{*}{ Treatments } & \multicolumn{15}{|c|}{ Micronutrient content in Potato tubers (ppm) } \\
\hline & & \multicolumn{5}{|c|}{2015} & \multicolumn{5}{|c|}{2016} & \multicolumn{5}{|c|}{ Pooled } \\
\hline & & $\mathbf{Z n}$ & $\mathbf{C u}$ & Mn & $\mathbf{F e}$ & $\mathbf{B}$ & Zn & $\mathrm{Cu}$ & Mn & Fe & $\mathbf{B}$ & $\mathbf{Z n}$ & $\mathbf{C u}$ & Mn & Fe & $\mathbf{B}$ \\
\hline 1 & $\begin{array}{l}\text { T1:Farmers } \\
\text { practice }\end{array}$ & 15.2 & 5.5 & 14.5 & 18.5 & 12.0 & 16.2 & 6.2 & 15.6 & 19.5 & 13.0 & 15.7 & 5.85 & 15.05 & 19.0 & 12.5 \\
\hline 2 & $\begin{array}{l}\text { T2:Recommen } \\
\text { ded Practice }\end{array}$ & 16.4 & 6.4 & 17.2 & 19.5 & 13.5 & 17.0 & 6.8 & 18.8 & 22.0 & 14.2 & 16.7 & 6.6 & 18.0 & 20.7 & 13.8 \\
\hline 3 & $\begin{array}{l}\text { T3:Alternate } \\
\text { Practice-1 }\end{array}$ & 18.5 & 7.4 & 18.2 & 21.6 & 14.6 & 19.4 & 7.2 & 19.7 & 24.5 & 15.2 & 18.9 & 7.30 & 18.9 & 23.0 & 14.9 \\
\hline 4 & $\begin{array}{l}\text { T4:Alternate } \\
\text { Practice-2 }\end{array}$ & 22.6 & 8.2 & 20.5 & 24.5 & 16.5 & 21.8 & 8.4 & 22.5 & 25.6 & 16.8 & 22.2 & 8.30 & 21.5 & 25.0 & 16.6 \\
\hline & CD (at 5\%) & 2.22 & 1.25 & 2.25 & 2.85 & 1.45 & 2.16 & 1.30 & 2.18 & 2.75 & 1.52 & 2.19 & 1.27 & 2.21 & 2.80 & 1.48 \\
\hline & SEM & 0.71 & 0.41 & 0.75 & 0.95 & 0.54 & 0.75 & 0.48 & 0.72 & 0.91 & 0.52 & 0.73 & 0.44 & 0.73 & 0.93 & 0.53 \\
\hline & $\mathrm{CV}(\%)$ & 5.67 & 6.25 & 6.40 & 6.05 & 5.47 & 6.25 & 5.50 & 6.8 & 4.78 & 6.81 & 6.02 & 5.87 & 6.60 & 5.41 & 6.14 \\
\hline
\end{tabular}

Table.5 Effect of foliar application of vegetable special on economics of crop

\begin{tabular}{|c|c|c|c|c|c|c|c|c|c|c|}
\hline \multirow{2}{*}{$\begin{array}{l}\text { S. } \\
\text { No. }\end{array}$} & \multirow[t]{2}{*}{ Treatments } & \multicolumn{3}{|c|}{ Gross Return (Rs/ha) } & \multicolumn{3}{|c|}{ Net Return (Rs/ha) } & \multicolumn{3}{|c|}{ B: C ratio } \\
\hline & & 2015 & 2016 & Pooled & 2015 & 2016 & Pooled & 2015 & 2016 & Pooled \\
\hline 1 & T1:Farmers practice & $1,36,950$ & 141750 & 137025 & 71800 & 79750 & 75775 & 2.19 & 2.28 & 2.23 \\
\hline 2 & T2:Recommended Practice & $1,42,950$ & 142200 & 142950 & 80900 & 79100 & 80000 & 2.28 & 2.25 & 2.26 \\
\hline 4 & T4:Alternate Practice-2 & $1,55,925$ & 153750 & 155925 & 94600 & 89950 & 92275 & 2.48 & 2.40 & 2.44 \\
\hline
\end{tabular}

Table.6 Effect of foliar application of vegetable special on number of tubers per 10 square meter

\begin{tabular}{|c|c|c|c|c|c|c|c|c|c|c|c|c|}
\hline \multirow{2}{*}{$\begin{array}{l}\text { Particulars } \\
\text { Tuber size /number }\end{array}$} & \multicolumn{3}{|c|}{ T-1 Farmers practice } & \multicolumn{3}{|c|}{ T2-Recommended Practice } & \multicolumn{3}{|c|}{ Alternate practice-1 } & \multicolumn{3}{|c|}{ Alternate practice-2 } \\
\hline & 2015 & 2016 & Pooled & 2015 & 2016 & Pooled & 2015 & 2016 & Pooled & 2015 & 2016 & Pooled \\
\hline$<25 \mathrm{~g}$ & 96.0 & 98 & 97 & 112.5 & 113.0 & 112.75 & 118.0 & 117.5 & 117.75 & 122.0 & 124.0 & 123 \\
\hline $25-50 \mathrm{~g}$ & 145.5 & 146.0 & 145.75 & 159.0 & 162.0 & 160.5 & 164.5 & 166.0 & 165.25 & 175.7 & 178.0 & 176.85 \\
\hline $50-75 \mathrm{~g}$ & 287.2 & 290.0 & 288.6 & 312.5 & 314.5 & 313.5 & 325.0 & 328.0 & 326.5 & 350.3 & 352.0 & 351.15 \\
\hline$>75 \mathrm{~g}$ & 378.0 & 275.0 & 326.5 & 395.0 & 392.0 & 393.5 & 412.5 & 415.0 & 413.75 & 425.5 & 428.0 & 426.75 \\
\hline $\begin{array}{l}\text { Total number of } \\
\text { tubers } / 10 \text { sqmt }\end{array}$ & 906.7 & 809 & 857.85 & 979 & 981.5 & 980.25 & 1020 & 1026.5 & 1023.25 & 1073.5 & 1082 & 1077.75 \\
\hline
\end{tabular}




\section{Number of tubers per 10 square meter}

Number of tubers per square meter differed among the treatments. The maximum total number of tubers were recorded in alternate practice-2 (1073, 1082 and 1077.7) during both the years and in pooled data and however was on par with alternate practice-1 (1020, 1026 and 1073.5) during both the years and in pooled data. The lowest number of tuber per 10 square meter was recorded in farmers practice during 2015, 2016 and in pooled data (906, 809 and 857.85$)$ and was on par with farmers and recommended practice which recorded 979, 981.5 and 980.25 tubers per 10 square meter. The higher number of tubers per 10 square meter was recorded due to combined effect of integrated management of both macro (NPK) and micronutrient ( $\mathrm{Zn}$, $\mathrm{Cu}, \mathrm{Mn}, \mathrm{Fe}$ and $\mathrm{B}$ ) in turn increased the number of tubers by 25 percent over farmers practice. These results are in agreement with findings of Mousavi et al., (2007). With respect size of tubers, maximum tubers recorded with more than $75 \mathrm{gm}$ of tuber in alternate practice-2 (426.75) followed by alternate practice-1, (413.75) recommended practice (393.5) and farmers practice (326.5). Similar trend was also followed with respect other size groups like <25g, 25-50g and 50-75 $\mathrm{g}$ (Table 6).

\section{Micronutrient content in potato tubers}

As regard to micronutrient content in tubers higher concentration of $\mathrm{Zn}, \mathrm{Cu}, \mathrm{Mn}, \mathrm{Fe}, \mathrm{B}$ and Mo were recorded in the treatment where foliar application of vegetable special @ 5g/lit along with RDF (22.2,8.3,21.5,25.0 and 16.6 $\mathrm{ppm}$ ) than recommended practice and farmers practice. These results are in agreement with findings of Malakouti (1999) (Table 4).

\section{Economics of crop}

As regard to economics of crop, the highest gross return was recorded in alternate practice-2 (Rs 1,55,925, 1,53,750 and 1,55,925) during 2015, 2016 and in pooled data over farmers practice (Rs. 1,36,950, $1,41,750$ and $1,37,025$ ) during both the years and in pooled data. Similarly the Net return was increased by Rs 92,475 compared to farmers practice (Rs 76,450). However in recommended practice and in alternate practice there was no much difference noticed and recorded net income of Rs 80,150 and Rs 83850 per hectare respectively. However increase in additional income of Rs. 16,500 was recorded compared to farmers practice (Table 5).

With respect of Economics of crop the higher B: C ratio was recorded with Alternate practice-2 + RDF (1:2.44) followed by alternate practice-1 (2.30) and recommended practice (2.26). The lowest B: C ratio was recorded in Farmers practice (2.23).

\section{References}

Gomez, K.A., and Gomez AA 1984. Statistical procedures for agricultural research. 2nd edn, John Wiley and Sons, New York, 680p.

Horvat, T., Poljak M, Lazarevic B, Svecnjak Z and Hanacek K 2014. Effect of foliar fertilizers on physiological characteristics of potato. Romanian Agricultural Research, 31: 159-165.

Jackson, M.L., 1973. Soil chemical analysis. Prentice Hall of India Pvt Ltd, New Delhi, India, 154p.

Malakouti, M.J., and Tehrani MM 1999. Effect of micronutrients in yield increase and improvement of crops quality. Tarbiat Modarres University Press.

Mehul Parmar, B.M., Nandre and Yogesh Pawar.2016. Influence of foliar supplementation of $\mathrm{Zn}$, Mnon yield and quality of potato. International Journal of Farm Sciences, 6(1): 69-73, 2016

Mohamadi, E., 2000. Study Effects of nutrient 
elements utilization methods $(\mathrm{Zn}, \mathrm{Mn}$ and $\mathrm{Mg}$ ) on increase performance quantitative and quality of two potato species. Jehad and Agriculture Ministry Final Report of Research Institute Reformand Providing Sapliny and Seed. Mousavi, S.R., Galavi M and Ahmadvand G 2007. Effect of zinc and manganese foliar application on yield, quality and enrichment on potato (Solanum tuberosum L). Asian Journal of Plant Sciences, 6: 1256-1260.
Paygozar, Y., Ghanbari A, Heydari M, Tavassoli A. 2009. Effect of foliar application of certain micronutrients on qualitative and quantitative characteristics of pearl millet (Pennisetum glacum) under drought stress. J. Agric. Sci., 3(10): 67-79

Uygur, V., Rimmer DL. 2000. Reactions of zinc with iron coated calcite surfaces at alkaline pH. Eur. J. Soil Sci., 51: 511516.

\section{How to cite this article:}

Channakeshava, S., T.S. Manjunathaswamy, H.K. Pankaja and Krishna Reddy, G.S. 2017. Effect of Foliar Application of Vegetable Special on Growth and Yield of Potato. Int.J.Curr.Microbiol.App.Sci. 6(9): 1348-1354. doi: https://doi.org/10.20546/ijcmas.2017.609.163 